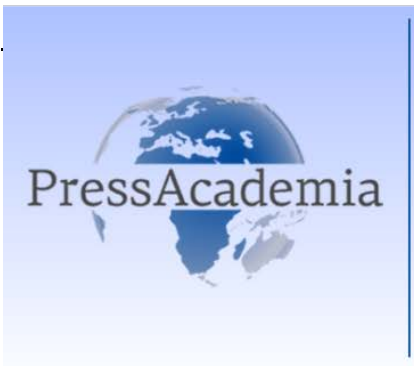

Press Academia Procedia

Global Business Research Congress (GBRC), May 26-27, 2016, Istanbul, Turkey.

\title{
PATIENT SATISFACTION IN THE CONTEXT OF TOTAL QUALITY MANAGEMENT:AN EXAMPLE OF SIVAS STATE HOSPITAL
}

\section{DOI: 10.17261/Pressacademia.2016118622}

\author{
Hatice Genc Kavas, Mehmet Celal Gultekin, Omer Fazil Emek \\ ${ }^{1}$ Mardin Artuklu Üniversitesi, haticegenc@outlook.com \\ ${ }^{2}$ Mardin Artuklu Üniversitesi, mehmetcelal@outlook.com \\ ${ }^{3}$ Mardin Artuklu Üniversitesi, ofemek@hotmail.com
}

\begin{abstract}
In particular, TQM applied in industry is of strategic importance for the company in a highly competitive environment. Therefore currently the service marketing began to adopt TQM. The tendency to learn with the aim of reaching better and innovation that occur in all TQM processes brings effectiveness and efficiency. The customer satisfaction is an important data to measure effectiveness. In this study, satisfaction survey was applied on 396 in patients discharged at Sivas State Hospital and as a result the answer has been sough twhether hospital uses TQM effectively or not from the point of view of the customer. Survey form includes 63 questions obtained through Factor analysis consisting 9 factors. Factors on which patients base their recommendation and preference of hospital are analyzed. The survey of what health and care services which are provided have low level of satisfaction and what should be done in this process are presented. In this study, it has been found that the hospital can use the TQM applications effectively but it possesses deficiencies on some occasions from the pointview of the customer (patient). In the future, measurements that will be obtained through financial, internal business and innovation and learning perspectives will be combined with this study and answer of how effectively and accurately the TQM applications are put into effect in the hospital will be presented.
\end{abstract}

Keywords: Total quality management, competition, healthcare, patient satisfaction , service quality JEL Codes: M10, M31, I11, M11

\section{TOPLAM KALITE YÖNETIMI BAĞLAMINDA HASTA MEMNUNIYETi: SIVAS DEVLET HASTANESI ÖRNEĞi}

\section{ÖZET}

Özellikle sanayide uygulanan TKY, yoğun rekabet ortamında işletmeler için stratejik öneme sahiptir. Bu nedenle hizmet pazarlamasında da artık benimsenmeye başlanmıştır. TKY'de tüm süreçlerde gerçekleşen öğrenme ile birlikte yenileşme ve daha iyiye ulaşma eğilimi, etkinliği ve verimliliği beraberinde getirmektedir. Müşteri memnuniyeti ise etkinlik ölçümlemesinde rol oynayan önemli bir veridir. Çalışmada Sivas Devlet Hastanesi'nde yatarak sağlık hizmeti alan ve taburcu olmuş 396 hasta üzerinde memnuniyet anketi uygulanmıs ve sonucunda hastanenin müşteri bakış açısıyla TKY uygulamalarını etkin bir şekilde kullanıp kullanmadığı sorusuna cevap aranmıştır. Anket formunda, faktör analiziyle elde edilen 9 faktörden oluşan 63 soru yer almaktadır. Hastaların hangi faktörlere dayanarak hastaneyi tavsiye ve tekrar tercih ettiklerinin analizi yapıımışır. Sunulan sağlık ve bakım hizmetlerinden hangilerinde tatmin seviyesinin düşük olduğu ve bu süreçte neler yapılması gerektiğinin cevapları sunulmuştur. Çalışmada müşteri (hasta) bakış açısıyla hastanenin TKY uygulamalarını etkin kullanabildiği ancak bazı süreçlerde eksikliklerin olduğu sonucuna varılmıştır. Gelecekte yapılacak finansal, içsel ve öğrenme/yenilik bakış açılarıyla elde edilecek ölçümlemeler bu çalışmayla birleştirilerek hastanede TKY uygulamalarının ne derece etkin ve doğru hayata geçirildiğinin cevabını sunabilecektir.

Anahtar Kelimeler: Toplam kalite yönetimi, rekabet, sağlık hizmetleri , hasta memnuniyeti, hizmet kalitesi JEL Kodları: M10, M31, I11, M11 


\section{GíRiş}

1990'lı yılların en temel ve genel çevresel değişmeleri olarak ortaya çıkan globalleşme, küresel rekabet, demokratikleşme ve insan hakları, bilgi işleme ve iletişim teknolojisindeki gelişmeler ve nihayetinde artan rekabet, yeni kavram ve tekniklerin doğumuna ortam hazırlamış hem de bu kavram ve tekniklerin uygulamalarını zorunlu hale getirmiş ve kolaylaştırmıştır (Koçel, 2014: 410). Bu bağlamda bütün dünyada 1980’li yıllardan itibaren, kurum ve kuruluşlarca artan bir oranda uygulanan bir "yönetim felsefesi" (Sarp, 2014: 121) olan ve özünde müşteriye üstün değer sunarak yüksek müşteri tatminini hedefleyen toplam kalite yönetimi (TKY) yine bu kavram, teknikler ve yönetim süreçleri arasında güncel olarak yerini bulmaktadır.

Piyasalarda yarışan şirketlerden küreselleşmeyle başa çıkmaya çalışan ülkelere ya da toplumsal örgütlere kadar her yerde rekabet vardır. Her kurum müşterisine üstün değer sunabilmek için bir stratejiye ihtiyaç duyar. Örgütler refahlarını artırmaktan ziyade, mevcut olanı ellerinde tutmak için rekabet etmek zorundadırlar. intiyaçların arttığı ama kaynağın az olduğu sanat, eğitim, sağlık ve hayırseverlik gibi alanlarda da bu zorunluluk yayılmaktadır. Bu durumda bugün her alandaki kuruluşların değer yaratmak zorunda olduğu aşikardır. Değer, müşterinin ihtiyaçlarını karşılama ya da aşma ve bunu etkin biçimde yapma yetisidir. Şirketler müşterilerine, ülkeler ise coğrafi iş konumları olarak değer sunmalıdırlar. Bu durum, ürün ya da hizmet üreten bir şirket için ne kadar geçerliyse, sağlık hizmeti sunan bir hastane ya da hayırsever katkılarda bulunan bir vakıf için de o kadar geçerlidir (Porter,2010: 9).

Rekabete uyum sağlamada ve hatta rekabette avantaj elde etmede önemli olan değeri belirleyen aktör müşteridir. Müşteri açısından "değer" kavramı, sunulan kaliteli ürün veya hizmet olarak nitelendirilebilir. Üstün değer ise bunun sürece yayılması yani kalitenin sürekli geliştirilmesi olarak ifade edilebilir. Kalitenin sürekli geliştirilmesi, Toplam Kalite Yönetimi'nin etkin bir şekilde uygulanmasına bağlıdır ve özellikle 1980'li yıllardan sonra TKY, işletme stratejilerinin temeli ve işletmelerin rekabet avantajı kaynağı olarak görülmektedir (Kıngır vd.,2009: 255-256).

\section{LITERATÜR TARAMASI}

\subsection{Toplam Kalite Yönetimi}

Kalite kavramı insanların ve sistemlerin "hata yapması" ve "mükemmele ulaşma isteği" gerçeğinden ortaya çıkmıştır (Durukan ve İkiz, 2007: 39). Günlük dilde halk arasında "en iyi, en hoş, en büyük, en pahalı ve en süper" karşıı̆̆ında kullanılmakla beraber genelde kullananlar tarafından "doğru işi doğru yapmak biçiminde" algılanmaktadır (King ve Cichy, 2006; 9). Yine "kalite"nin müşterilerin ihtiyaçlarına uygunluk ölçüsü olduğu söylenebilir. Kalite müşterinin zihninde olandır, yani tüketici aldığı ürün veya hizmetten mutsuzsa o ürün veya hizmet yüksek kalitelidir denilemez. Bu anlatımdan ortaya çıkarak, müşterinin memnuniyeti baz alınarak kalite kavramı tanımlanmaktadır.

TKY ise; müşteri beklentilerini her şeyin üzerinde tutan, organizasyonda mal ve hizmet üretimi sırasında gerçekleştirilen tüm faaliyetlerin geliştirilmesine odaklı, süreçlerde tam katılımı hedefleyen, iç ve dış müşteri tatmininin artırıması ve bunun sonucunda müşteri bağlılığını gerçekleştirmek amacıyla işletmede alınan sonuçların iyileştirilmesine dayanan, müşteri tarafından tanımlanan kaliteyi tüm faaliyetler sürecinde ortaya çıkaran çağdaş bir yönetim felsefesidir.

Kalite yönetimine en önemli ve uzun soluklu katkı sağlayan araştırmacılar Philip b. Crosby (sıfır hata), W. EdwardsDeming (PUKÖ döngüsü), Armond V. Feigenbaum, Kaorulshikawa (kalite çemberleri), Joseph M. Juran (ekip çalışması), John Oakland, SheigoShingo ve GenichiTaguchi'dir ve bu araştırmacıların yapmış olduğu çalışmaları kalite konusunu istatistik uygulamalardan ibaret olmaktan çıkarmış, tüm işletme çalışanlarının sorumluluğu haline getirmiştir. Hatta daha da ileri giderek kalite sadece üretimi yapan işletmenin sorunu olmaktan çıkmış, nihai ürünün müşteriye ulaşmasına kadar üretim ve dağıtım zinciri üzerinde yer alan tüm işletmelerin sorunu ve sorumluluğu haline gelmiştir. Yani kalite olayı "teknik" bir uygulama olmaktan çıkarak bir "felsefe" haline dönüşmüştür. Bu süreçte gelişen TKY bir moda değil, yönetim düşünce ve uygulamalarında köklü bir değişimi ifade eden bir yaklaşım olarak kendini göstermektedir (Beckford, 1998: 49-50, Koçel, 2014: 438-441, Sarp, 2014: 167). 
Müşteri odaklı bir yaklaşımla, “kaliteyi müşteri tanımlar” ilkesi TKY'ye açıklık getirmektedir. MichealPorter, zorlu koşulların saldıılarına karşı işletmelerin daha az kııılgan olmalarıı 5 güç farkındalı̆ına bağlamaktadır ve bu 5 güç modelinde "alıcıların gücü" önemli bir yere sahiptir (Porter,1979: 137). "Alıcılar" olarak tanımlanan "müşteriler" sektörün kârlıı̆ıına mâl olacak şekilde, fiyatları aşă̆ı çekmeye zorlayarak, daha iyi kalite ve daha fazla hizmet için pazarlık ederek ve rakipleri birbirine düşürerek sektörle rekabet ederler (Porter, 2000: 30). Bu bağlamda TKY piyasada müşterinin tam anlamıyla tatmin edilmesi hedefine kilitlenmiş bir yönetim tarzıdır.

TKY sağlık kuruluşlarına; müşteri intiyaçlarını belirleme, tıbbi hataların sıklı̆ıını ve şiddetini azaltma, gelişen süreçler ve en iyi uygulamalar için kıyaslama yapma ve en uygun bakımı sunma olanağını sağlar. TKY uygulamaları, daha kaliteli bakımı, sürekli artan hasta memnuniyetini, çalışan memnuniyetini ve bağlıı̆ı̆ıı, artan verimlilik ve kârlıı̆ı̆ beraberinde getirebilmektedir. Sanayide uygulanmakta olan TKY'nin başarısı sağlık yöneticilerini bu felsefenin sağlık sektöründe çalışıp çalış̧madığını incelemeye teşvik etmiştir. Bu nedenle birçok sağlık kuruluşu, sağık hizmeti sunumunun çıktılarının kalitesini ve verimliliğini artırmak için TKY ilkelerini uygulamaya koymaktadırlar(Mosadeghrad, 2015: 544-545).

TKY başarının anahtarı olarak kaliteye odaklanan yönetim yaklaşımı (Saunders ve Graham,1992: 244) olup bazı temel değerlere / ilkelere dayanmaktadır (Chao vd., 2015: 159-160; Eren, 2001: 109-116; Kaya ve Taner, 2005: 357-358, Sarp, 2014: 124-155):

- Üst yönetimin desteği ve liderlik

- Müşteri odaklılık

- Çalışanların katııımı ve ekip çalışması

- $\quad$ Çalışanların eğitimi

- $\quad$ Sürekli geliştirme (Kaizen)

- Hata önleme / sıfır hata

- $\quad$ Etkili ölçümleme

- Tedarikçi yönetimi

- Kıyaslama

- $\quad$ Süreç yönetimi

\section{VERI VE YÖNTEM}

\subsection{Amaç ve Yöntem}

Araştırmanın temel problemi Sivas Devlet Hastanesi'nde yatarak sağlık hizmeti alan hastaların hizmetten tatmin olma boyutunun ne olduğudur. Bununla beraber; hastaların hangi hizmetlerden memnun olup, olmadığı; aynı hastaneyi tekrar tercih etmelerini ve başkalarına tavsiye etmelerini etkileyen faktörlerin neler olduğu ve Toplam Kalite Yönetimi'nin sağlık hizmeti süreçlerine uyarlanıp uyarlanamadığı belirlenmeye çalışıımıştır.

Çalışmada Sivas Devlet Hastanesi'nin 18 servisinde Nisan-Mayıs 2011 tarihleri arasında yatarak sağlık hizmeti alan 3712 hasta içerisinden rassal seçilen 396 hasta üzerinde yüz yüze anket yöntemi kullanılarak yapılmıştır. Örneklem hacmi belirleme formülü aşağıdaki gibidir;

$$
\begin{aligned}
n & =\frac{N \cdot t^{2} \cdot p \cdot q}{d^{2} \cdot(N-1)+t^{2} \cdot p \cdot q} \\
\mathrm{~N} & =\text { Hasta sayısı (poliklinik, yatan) } \\
\mathrm{n} & =\text { Örnekleme alınacak birey sayısı } \\
\mathrm{p} & =\text { İncelenecek olayın görülüş sıklığı (olasılığı }=0,5)
\end{aligned}
$$


$q$ = İncelenecek olayın görülmeyiş sıklığı ( $1-p=0,5$ )

$t=$ Belirli serbestlik derecesinde ve saptanan yanılma düzeyinde $t$ tablosunda bulunan teorik değer $(1,96)$

$d=$ Örneklem hatası $(0,05)$

Verilerin toplanması için, yabancı ve yerli literatür taranarak ortak noktalar baz alınmış ve öncelikle Türkiye şartlarında uygulanabilirliği kontrol edilerek oluşturulmuş "yatan hasta memnuniyeti değerlendirme anket formu” kullanılmıştır. Anket 63 sorudan oluşmaktadır. Soruların ilk 6'sı hastaların demografik özelliklerini öğrenme amaçlı olup, hastaların aldıkları hizmetlere karşı duydukları memnuniyet düzeyleri belirlenmeye ve hizmet kalitesi irdelenmeye çalışılmıştır. Anket, hastaların baskı altında cevap vermelerini engellemek ve araştırmanın daha sağlıklı olması için taburcu oldukları sırada uygulanmıştır. Hastaların aldıkları servis hizmetlerine ilişkin değerlendirmelerini içeren sorularda 5'li Likert tipi ölçekleme kullanılmıştır (5-Çok iyi, 4-iyi, 3-Orta, 2-Kötü, 1-Çok kötü).

İstatistiki analizler için PASW Statistics 18 programından faydalanılmıştır. Program yardımıyla; frekans dağılımı, yüzdeler, aritmetik ortalama, standart sapma, güvenilirlik analizi, faktör analizi, parametrik ve non-parametrik testler kullanılarak analizler yapılmıştır.

\section{BULGULAR VE TARTIŞMA}

\subsection{Bulgular ve Değerlendirme}

Araştırmamızda katılımcı olan hastaların demografik özellikleri ve tedavi gördükleri servisler Tablo 1'de gösterilmiştir.

Tablo 1: Hastaların Demografik Özellikleri ve Servisler

\begin{tabular}{|c|c|c|c|c|c|c|c|c|}
\hline & $f$ & $\%$ & & $f$ & $\%$ & & $f$ & $\%$ \\
\hline Cinsivet & & & Meslek & & & Tedavi Servisi & & \\
\hline Erkek & 86 & 21,7 & Serbest & 17 & 4,3 & Dahiliye & 30 & 7,6 \\
\hline \multirow[t]{2}{*}{ Kadın } & 310 & 78,3 & işçi & 38 & 9,6 & Nöroloji & 11 & 2,8 \\
\hline & & & Memur & 32 & 8,1 & Çocuk Enfeksiyon & 31 & 7,8 \\
\hline$\underline{\text { Yaș }}$ & & & Emekli & 24 & 6,1 & Genel Cerrahi & 25 & 6,3 \\
\hline$\overline{15-25}$ & 106 & 26,8 & Evhanımı & 266 & 67,2 & Üroloji & 13 & 3,3 \\
\hline $26-35$ & 127 & 32,1 & işsiz & 3 & 0,8 & Çocuk Cerrahi & 16 & 4,0 \\
\hline $36-45$ & 82 & 20,7 & Diğer & 16 & 4,0 & Ortopedi & 13 & 3,3 \\
\hline $46-55$ & 40 & 10,1 & & & & K.D Septik & 33 & 8,3 \\
\hline \multirow[t]{2}{*}{56 ve üstü } & 41 & 10,4 & & & & K.D Aseptik & 55 & 13,9 \\
\hline & & & Güvence & & & K.D Ameliyat & 27 & 6,8 \\
\hline Eğitim Durumu & & & $\overline{\text { Memur }}$ & 59 & 14,9 & KBB & 9 & 2,3 \\
\hline Okur-yazar & 35 & 8,8 & işçi & 167 & 42,2 & Yeni Doğan & 33 & 8,3 \\
\hline Ilkokul & 106 & 26,8 & Memur Emeklisi & 31 & 7,8 & Göz & 10 & 2,5 \\
\hline Ortaokul & 107 & 27,0 & Bağkur & 34 & 8,6 & Cildiye & 2 & 0,5 \\
\hline Lise & 92 & 23,2 & Yeşil Kart & 89 & 22,5 & Süt Çocuğu 1 & 29 & 7,3 \\
\hline Yüksek okul & 26 & 6,6 & Yurt dışı & 1 & 0,3 & Süt Çocuğu 2 & 39 & 9,8 \\
\hline Üniversite & 29 & 7,3 & Güvence yok & 5 & 1,3 & Beyin Cerrahi & 2 & 0,5 \\
\hline Lisansüstü & 1 & 0,3 & Diğer & 10 & 2,5 & Fizik Tedavi & 18 & 4,5 \\
\hline
\end{tabular}

Araştırmaya katılan 396 hastanın \%78'ini kadınlar oluşturmaktadır. Kadın ve çocuk hastalıkları servislerinin Sivas ilinde mevcut olan 2 devlet hastanesinden sadece Sivas Devlet Hastanesi'nde bulunması, bu çokluğun nedeni olabilmektedir. Ankete katılanların \%32'sinin 26-35 yaş aralığında olduğu görülmektedir. Katılımcıların yarısından fazlası ilköğretim mezunudur. Büyük çoğunluğu ev hanımlarından ve işçilerden oluşmaktadır. Anketin güvenilirlik analizi sonucu Cronbah Alpha "0,975" değerine ulaşılmıştır. Ankete uygulanan faktör analizinde benzer özellik taşıyan değişkenler 9 grupta toplanmıştır. Oluşan bu 9 faktör toplam varyansın \%69'unu açıklamakta olup, 5 değişken kapsam dışı bırakılmıştır. Faktörler ve cronbachalpha değerleri Tablo 2'de gösterilmiştir. 
Tablo 2: Faktör Analiz Sonuçları

\begin{tabular}{lll}
\hline & Faktörler & Cronbach Alpha \\
\hline 1. Faktör & Hasta kabul &, 680 \\
2. Faktör & Servis Düzeni ve Temizlik &, 850 \\
3. Faktör & Yemek &, 860 \\
4. Faktör & Hemşireler &, 956 \\
5. Faktör & Doktorlar &, 619 \\
6. Faktör & Tedavi ve Bakım &, 932 \\
7. Faktör & Ziyaretçi ve Refakatçi &, 853 \\
\hline 8. Faktör & Taburcu Sonrası Genel Değerlendirme &, 942 \\
\hline 9. Faktör & Sosyal tesis &, 765 \\
\hline
\end{tabular}

\subsection{Araştırmanın Hipotez Testleri}

Tablo 1'de gösterilen demografik özellikler ve tedavi görülen servislere göre gruplar arası farklılık hipotezleri sonuçlarına Levene, T, Anova, Tukey HSD, Tamhane 2, Brown Forsythe ve Kruskal Wallis testlerinden faydalanılarak ulaşıımıştır $(p<0,05)$. Araştırmanın hipotezleri aşağıdaki gibidir.

HO: Gruplar ilgili madde bakımından farklılık göstermemektedir.

H1:Guplar ilgili madde bakımından farklılık göstermektedirler.

Buna göre;

Yatan hastalardan kadın ve erkekler Sadece "Hasta Kabul" faktörü (Servise yatış işleminin hızı, Yatış işlemini yapan personelin nezaketi, Hastane kuralları hakkında verilen bilgi yeterliliği) bakımından birbirlerinden farklılık göstermişlerdir ( $F=1,846, p=0,007)$. Yaş, eğitim durumu, meslek ve sağlık güvencesi kategorilerinde ise $H 1$ hipotezi reddedilmiştir yani gruplar faktörler bazında birbirleri ile anlamlı düzeyde farklılık göstermemişlerdir. Bununla beraber ise tedavi görülen servis bazında gruplar birbirleri ile $p=0,05$ anlamlılık düzeyinde farklılık göstermişlerdir. Servislerde hizmet sağlayıcılarının birbirinden farklılık göstermesi bu sonucu elde etmede önemli bir etkendir denilebilir.

Tablo 3: Hastane Hizmetlerinin Değerlendirilmesi Dağılımı

\begin{tabular}{llc}
\hline $\begin{array}{l}\text { Yeniden hastaneye gitmeniz gerekirse bu } \\
\text { hastaneyi tercih eder misiniz? }\end{array}$ & $\mathbf{f}$ & $\mathbf{\%}$ \\
\hline Kesinlikle tercih etmem & 6 & 1,5 \\
Tercih etmem & 4 & 1,0 \\
Fikrim yok & 45 & 11,4 \\
Tercih ederim & 191 & 48,2 \\
Kesinlikle tercih ederim & 150 & 37,9 \\
Toplam & $\mathbf{3 9 6}$ & $\mathbf{1 0 0 , 0}$ \\
\hline
\end{tabular}

Sivas Devlet Hastanesinde yatarak sağlık hizmeti alan hastaların taburcu sonrası hastaneyi tekrar tercih ve tavsiye etme eğilimleri Tablo 3 ve 4'te gösterilmektedir. Tabloya göre 396 hasta ile yapılan görüşmede hastaların \%86'sı bu hastaneyi tekrar tercih edeceklerini söylemiştir. \%2,5 oranında ise hastalar tekrar tercih etmeyeceklerini dile getirmişlerdir. 
Tablo 4: Hastane Hizmetlerinin Değerlendirilmesi Dağılım

\begin{tabular}{lll}
\hline $\begin{array}{l}\text { Bu hastaneyi çevrenize tavsiye eder } \\
\text { misiniz? }\end{array}$ & f & \% \\
\hline Kesinlikle tavsiye etmem & 5 & 1,3 \\
\hline Tavsiye etmem & 3 & 0,8 \\
Fikrim yok & 39 & 9,8 \\
Tavsiye ederim & 197 & 49,7 \\
Kesinlikle tavsiye ederim & 152 & 38,4 \\
Toplam & $\mathbf{3 9 6}$ & $\mathbf{1 0 0 , 0}$ \\
\hline
\end{tabular}

Tablo 4'te hastaneyi başkalarına tavsiye etme konusunda ise hastaların \%88'i tavsiye edeceklerini belirtmiş buna karşın \%2'lik bir kesim tavsiye etmeyeceklerini söylemiştir. Hastaların hastaneyi tekrar tercih ve tavsiye etme eğilimlerinin hizmet faktörleri ile açıklanıp açıklanmayacağı sorusuna çoklu regresyon analizi ile bakılmıştır. Tablo 5 ve Tablo 6'da eğilimlerle hizmet kalitesi ilişkisi analiz edilmiştir.

Tablo 5: Çoklu Regresyon Analizi ( Hastanenin Tekrar Tercih Edilmesi ile Hizmet Kalitesi ilişkisi)

\begin{tabular}{|c|c|c|c|}
\hline$R=0,834 \quad R^{2}=0,696$ & Düzeltilmiş $R^{2}=0,688$ & $F=97,968$ & Anlamlılık Düzeyi $=0,000$ \\
\hline Değişkenler & Beta Katsayısı & t Değeri & Anlamlılık Düzeyi \\
\hline Hasta Kabul & 0,008 & 0,237 & 0,812 \\
\hline Servis ve Temizlik & 0,031 & 0,790 & 0,430 \\
\hline Yemek & $-0,101$ & $-2,848$ & $0,005^{*}$ \\
\hline Hemşireler & $-0,088$ & $-1,825$ & 0,069 \\
\hline Doktorlar & 0,095 & 2,634 & $0,009 *$ \\
\hline Tedavi ve Bakım & 0,193 & 3,699 & $0,000^{*}$ \\
\hline Ziyaretçiler ve Refakat & 0,053 & 1,234 & 0,218 \\
\hline Taburcu Sonrası Değer & 0,656 & 11,805 & $0,000^{*}$ \\
\hline Sosyal Tesis & 0,010 & 0,278 & 0,782 \\
\hline
\end{tabular}
$p<0,01$

Tablo 5'te gösterilen analiz sonucunda hastaların hastaneyi tekrar tercih etme durumlarıyla ilgili değişimin \%69'u model tarafından açıklanmakta olup faktörlerle, tercih etme eğilimi arasında pozitif bir ilişki olduğu görülmektedir. Analize göre; yatan hastaların hastaneyi tekrar tercih etme eğilimlerini açıklayan faktörler "F6:Tedavi ve Bakım", "F8:Taburcu Sonrası Genel Değerlendirme”, "F3:Yemek" ve "F5:Doktorlar" dır. Tercih etmedeki öncelik "Tedavi ve Bakım Faktörü" ile (Bakım veya tedavi için bekleme süresi, tedavi ve bakımla amaçlananların açıklanması, oluşabilecek yan etkilerin açıklanması, hastaya ve yakınına doktorla konuşma fırsatı verilmesi, gereken muayene süresinin ayrılması, tedavi ve bakım kararlarının hastaya danışılması) açıklanmaktadır. Aynı öneme sahip olan "Taburcu Sonrası Genel Değerlendirme” faktörü (Taburcudan sonraki sağlık durumu, Taburcu işleminin hızı, Evdeyken yapılacaklar bilgisinin verilmesi, Karşılaşılacak sorunlar hakkında açıklama, Hizmet alınan sürede gösterilen ilgi, Servis çalışanlarının ekip uyumu, Araç ve gereçlerin modernliği, Tıbbi hizmetlerden yararlanma kolaylığı, Genel olarak alınan sağlık hizmeti, Hastane genelinin temizliği ve düzeni, Genel kalite) olmuştur. 3. sırada "Yemek" faktörü (Yemeklerin sıcaklığı, Yemek kalitesi, Yemek servisini yapan personelin nezaketi) gelmektedir. 4. olarak "Doktorlar" Faktörü (Doktorların anlaşılır şekilde konuşması, Doktorlara karşı duyulan güven, Doktorların çağrıya cevap vermesi, Doktorların verdiği bilgi yeterliliği, Doktorları görmedeki kolaylık, Doktorların nezaketi, Doktorların mahremiyete karşı titizliği) hastaların Sivas Devlet Hastanesi'ni tekrar tercih etmedeki değişimi anlamlı bir şekilde açıklamaktadır. 
Tablo 6: Çoklu Regresyon Analizi (Hastanenin Tavsiye Edilmesi ile Hizmet Kalitesi iliş̧kisi)

\begin{tabular}{|c|c|c|c|}
\hline$R^{2}=0,664$ & Düzeltilmiş $R^{2}=0,657$ & $F=84,919$ & Anlamlılık Düzeyi $=0,000$ \\
\hline Değişkenler & Beta Katsayısı & t Değeri & Anlamlılık Düzeyi \\
\hline Hasta Kabul & $-0,006$ & $-0,179$ & 0,858 \\
\hline Servis ve Temizlik & 0,055 & 1,316 & 0,189 \\
\hline Yemek & $-0,102$ & $-2,760$ & $0,006 *$ \\
\hline Hemşireler & $-0,047$ & $-0,927$ & 0,354 \\
\hline Doktorlar & 0,121 & 3,186 & $0,002 *$ \\
\hline Tedavi ve Bakım & 0,221 & 4,022 & $0,000^{*}$ \\
\hline Ziyaretçiler ve Refakat & 0,014 & 0,300 & 0,764 \\
\hline Taburcu Sonrası Değer & 0,596 & 10,221 & $0,000^{*}$ \\
\hline Sosyal Tesis & $-0,003$ & 0,088 & 0,930 \\
\hline
\end{tabular}

Tablo 4'teki analize göre yine yatarak sağlık hizmeti alan hastaların Sivas Devlet Hastanesi'ni başkalarına tavsiye etme eğilimi ile hastane hizmet faktörleri arasında pozitif bir ilişki olduğu görülmektedir. Model bu değişimin \%66'sını açıklayabilmektedir. Tercih etme eğiliminde olduğu gibi ilgili hizmet faktörleri, önemlilik sırasıyla F6, F8, F3 ve F5 faktörleridir. Bu 4 faktör hizmetlerinin kalite düzeyi hastaların tekrar tercihlerinde ve tavsiye etmelerinde en önemli rolü teşkil etmektedir. Hastaneler, özellikle tedavi ve bakım süreçlerine hastanın da kişisel katılımını sağlayarak en hızlı ve etkin şekilde sağlık hizmetini sağlamalıdırlar. Hizmet sağlayıcılarının ekip uyumunun hayati önem arz etmesi, hastaların kalite algısında da etkin rol oynamaktadır. Doktorların hastahekim ilişkisindeki davranış ve tutumları hastaların tercih algılarında etkili olmaktadır. Gülmez ve Kitapçı́nın (2008) yaptıkları çalışmada ise "doktorlar" ve "hemşireler" faktörleri tercih ve tavsiye eğiliminde önemlilik derecesine sahip çıkmıştır. Bu nedenle genel olarak doktor tavır ve tutumlarının, hastaların hastane kalite algısında önemli bir etken olduğu söylenebilir. Makinelerin modernliği, temizlik ve yemek gibi faktörler yardımcı unsurlar olmalarına rağmen bu çalışmada hizmet kalitesi algısında önemli dilimde yer almaktadırlar.

Bu bağlamda, sağlık hizmeti sağlayıcıları hasta memnuniyetinin artırılması için hastanın etkin katılımının da sağlandığı bir tedavi sürecini hızı şekilde gerçekleştirmeli, taburcu sonrası süreç takip edilerek hastaya bilgi aktarılmalı, özellikle hekimler ve diğer çalışanların hastalara ilgi ve yakınlık göstermeleri sağlanmalı ve bunlarla beraber yemek ve genel temizlik konularında hassas davranmalıdırlar.

Tablo 7: K. D. Septik, K. D. Ameliyat ve KBB servisleri, Tercih - Tavsiye Eğilimi ve Faktör Ortalamalar

\begin{tabular}{|c|c|c|c|c|c|c|c|c|c|c|c|}
\hline & Tercih & Tavsiye & F1 & $\mathbf{F} 2$ & F3 & $\mathrm{F} 4$ & F5 & F6 & F7 & F8 & F9 \\
\hline Septik & 3,727 & 3,848 & 4,040 & 3,878 & 3,353 & 3,965 & 3,887 & 3,424 & 3,469 & 3,672 & 3,434 \\
\hline Ameliyat & 3,703 & 3,666 & 4,000 & 3,976 & 3,876 & 4,084 & 3,682 & 3,654 & 3,916 & 3,878 & 3,716 \\
\hline K.B.B & 3,777 & 3,888 & 4,555 & 3,930 & 3,444 & 4,000 & 5,000 & 3,907 & 3,611 & 3,949 & 3,888 \\
\hline
\end{tabular}

Servisler bazında sağlık hizmeti alan hastaların genel ortalamalarının "iyi” düzeyinde olması, hastanenin hasta memnuniyetini sağladığını gösterebilmektedir. Sistemin alt bileşenlerine baktığımızda ortalamayı düşüren ve "vasat" düzeyine yaklaştıran 3 servis görünmektedir. "Kadın Doğum Septik" ( $n=33$ ), "Kadın Doğum Ameliyat" $(n=27)$ ve "K.B.B" ( $n=9)$ servislerinin faktör bazında memnuniyet ortalamaları Tablo 7'deki gibidir. TKY'de hedef maksimum müşteri (hasta) memnuniyetini sağlamaktır. SDH'ta bu hedefe ulaşmak için de sistemin bileşenlerine inmek gerekmektedir. 3 servis bazında memnuniyet düzeylerinin genel tatmini düşürmesi bu servislerdeki süreçlerde hataların olduğunu göstermektedir ve hastane yönetimi bu hatalardan kaynaklı hizmet sunumunda önlemler almalıdır.

\section{SONUÇ}

TKY'nin başarılı bir şekilde uygulanması, daha etkin ve verimli süreçlerin tasarlanmasını sağlayarak ürün ve hizmet kalitesini artırmakta, kaynak israfını azaltmakta ve böylelikle yüksek verimliliği beraberinde 
getirmektedir. Bu kazanımlara ek olarak Yunis ve arkadaşlarının yaptığı çalışmada (Yunis vd., 2013: 707) TKY'nin rekabet avantajı elde etmede ve korumada stratejik bir kaynak olduğu görülmektedir.

Sivas Devlet Hastanesi yöneticileri süreçlerde Toplam Kalite Yönetimi Felsefesi'ni benimsediklerini söylemişlerdir. Müşteri (hasta) bakış açısıyla ortaya çıkan tatmin düzeyi, uygulamada hastanenin başarılı olduğu sonucuna ulaştırabilir. Ancak TKY bütün süreçleri optimize etmeye odaklı bir felsefe olduğundan, tatmin düzeyi "vasat"a yakın çıkan "kadın doğum septik", "kadın doğum ameliyat" ve K.B.B" servislerinde değişime gidilmesi gerektiği sonucuna ulaşılmaktadır. Yine hastanenin, hastalarla etkin iletişimin sağlandığı bir tedavi süreci gerçekleştirmesi gerekliliği tatmin düzeyinde önemli bir rol oynamaktadır. Bunlarla beraber çalışan personelin, koordineli bir şekilde çalışması ve sahip oldukları tutum ve davranışlarının iyileştirilmesi hasta memnuniyetini artırmada etkinliği sağlayacaktır. "Yemek" faktörünün tekrar tercih ve başkalarına tavsiye konusunda önemlilik payına sahip olması, yemek hizmetinin sağlanmasında da önlemler alınması gerekliliğini ortaya koymaktadır. Tatmin düzeyinde "sosyal tesis" faktöründen $(3,942)$ sonra en düşük memnuniyet seviyesine sahip olan "yemek" faktörü $(3,960)$ gelmektedir. Özetle yemek hastaların manevi ve fiziki iyileşmesinde önemli bir etkendir ve tedavi ve bakım sürecinin bir parçası olan yemeklerin temizliğinin, lezzetinin, sıcaklığının ve sunumunun beklenilen düzeyde olmasına dikkat edilmelidir. Ayrıca yemek hizmeti sağlayan personelin de nazik bir iletişim içinde bulunması gerekmektedir. Bununla beraber sosyal tesis faktörünün memnuniyet düzeyinin çok düşük olmasına rağmen hastaların, Sivas Devlet Hastanesi'ni tekrar tercih ve başkalarına tavsiye etmesi konusunda anlamlı derecede ilgisi bulunmamaktadır. Bu da hastaların konaklamadan ziyade tedavi ve bakım konularında tercih belirttiklerini gösterebilmektedir.

Görüldüğü gibi TKY uygulamalarında istenilen başarıyı elde etmek için, sağıı hizmeti sağlayıcıları bir sistem olan hastanenin bütün süreçlerinde iyileştirmeye gitmelidir. Sürece değer katan bütün faaliyetler konusunda, paydaşlara gerekli bilgiler verilmeli ve eğitilmelidirler. Sonuçta elde edilecek etkinlik hasta tatminini artırmada stratejik bir önem taşımaktadır.

Sağlık alanında diğer sektörlerdeki gibi alıcıların gücüne odaklanıldığında daha farklı bir yapı görmek mümkündür. Küresel olarak sağlık alanında tüketicilerin, sağlayıcılar ve tedaviler hakkında seçim yapma şansının pek olmaması ve ellerindeki kısıtlı bilgi düzeyi göz önüne alındığında tüketici bilinçli kararlar alacak durumda değildir (Porter, 2010: 447). Bu da müşteri olarak tanımladığımız hastaların "alıcı gücü" penceresinden zayıf olduğunu bize göstermektedir ve hastanelerin hastalara karşı ellerinde bulundurdukları bir avantaj olarak karşımıza çıkmaktadır. TKY’nin müşteri odaklılık kavramının, bu bağlamda sağlık kuruluşlarında biraz daha fonksiyonundan uzaklaştığı söylenebilir.

Sivas'ta 2 kamu, 1 özel ve 1 de üniversite hastanesi sağlık hizmeti sunmaktadır. Bu nedenle hastaların tercih alternatifleri azdır. Bu bağlamda alıcıların gücünün zayıflaması şehirdeki hastaneler için bir avantaj oluşturmaktadır. Sağıık sektöründe rekabetin yerel kalması hastane süreçlerinin iyileştirilmesinde yavaş hareket edilmesini beraberinde getirmektedir. Ancak TKY'de hedef en iyiye ulaşmak olduğundan sürekli gelişme ve öğrenmeyle beraber mükemmele doğru bir yolculuk vardır. Bu nedenle özellikle yerel rekabetin gözlendiği ve az olduğu sağlık sektöründe dahi yönetim ekonomideki en iyi olma eğilimini her zaman barındırmalı ve bu yönde hareket etmelidir.

Varılan bu sonuçla beraber bundan sonraki süreçte, çalışmamızda müşteri (hasta) bakış açısıyla TKY uygulamalarının başarılı olduğu söylenebilen Sivas Devlet Hastanesi'nde bu sonucu desteklemek için diğer bakış açılarıyla (içsel bakış açısı, finansal bakış açısı, öğrenme/yenilik bakış açısı) (Kaplan ve Norton, 1992: 72) sistemin ele alınması ve ölçümlenmesi Toplam Kalite Yönetimi uygulamalarının Sivas Devlet Hastanesi hizmetlerinin optimizasyonu üzerindeki etkisini açığa çıkarmada yardımcı olacaktır. 


\section{KAYNAKLAR}

Beckford, J. (1998), Quality: A critical Introduction, Routledge Publishing, London.

Chih-Yang, C., Hung-Ming, H., Fang-Chih, H., Kung-Huang, L., Jia-Wen, L. (2015), "Total quality management and human resources selection: A case study of the national teacher selection in Taiwan", Total Quality Management\&Business Excellence, 26(2): 157-172.

Durukan, M. B. ve İkiz, A. K. (2007), “DenetimKalitesi, Kalite ve HizmetKalitesineilişkinModeller: KavramsalÇerçeve”. Mali ÇözümDergisi, Sayı: 82, iSMMMO YayınOrganı: 36-62.

Eren, E. (2001), Yönetim ve Organizasyon, 5. Baskı, Beta BasımYayımDağıtım A.Ş., İstanbul.

Gülmez, M. ve Kitapçı, O. (2008), “HastaneHizmetKalitesi ve BirUygulama”, H.Ü. İktisadi ve İdariBilimlerFakültesiDergisi, 26(1): 165-186.

Kaplan, R. S. ve Norton, D. P. (1992), “The Balanced Scorecard - Measures that Drive Performance”, Harvard Business Review, 70(1): 71-79.

Kıngır, S., $\quad$ Karagöz, $\quad$ Y., $\quad$ Yıldız, $\quad$ M. $\quad$ S.-Ağraş, $\quad$ S. $\quad$ (2009), "ToplamKalite ileilgiliÇalışmalaraKatılımDüzeyininBelirlenmesineYönelikAraştırma”, Atatürk ÜniversitesiSosyalBilimler Enstitüsü Dergisi, 13(2): $255-278$.

King, J. H. ve Cichy R. F. (2006), Managing for Quality in the Hospitality Industry, Upper Saddle River Publication, New Jersey.

Koçel, T. (2014), İşletmeYöneticiliği, Genişletilmiş 15.Baskı, Beta BasımYayınDağıtım A.Ş., İstanbul.

Mosadeghrad A. M. (2015),"Developing and validating a total quality management model for healthcare organisations", The TQM Journal, 27(5): $544-564$

Porter, M. E. (1979), “How Competitive Forces Shape Strategy”, Harvard Business Review, 57(2): 137-145.

Porter, M. E. (2000), RekabetStratejisi, (çev. GülenUlubilgen), SistemYayıncılık, İstanbul.

Porter, M. E. (2010), RekabetÜzerine, (çev. KıvançTanrıyar), Optimist Yayınları, İstanbul.

Sarp, N. (2014), ToplamKalite Yönetimi Uygulamaları, DesenOfset, Ankara.

Saunders, I. W. ve Graham, M. A. (1992), "Total Quality Management in the Hospitality Industry", Total Quality Management, 3(3): 243255.

Yunis, M. Jung, J., Chen, S. (2013),"TQM, Strategy, and Performance: a Firm-Level Analysis", International Journal of Quality \& Reliability Management, 30(6): 690-714. 